\title{
Voltammetric Determination of Vanadium(V) and Vanadium(IV) through the Formation of a 12-Molybdovanadate(V) Complex
}

\author{
Sadayuki Himeno ${ }^{\dagger}$, Kohji Kusuyama, Masashi Hashimoto and Nobuhiro Ishio \\ Department of Chemistry, Faculty of Science, Kobe University, Nada, Kobe 657-8501, Japan
}

\begin{abstract}
A simple voltammetric method has been developed for the determination of $\mathrm{V}(\mathrm{V})$ and $\mathrm{V}(\mathrm{IV})$. When a mixture of $\mathrm{V}(\mathrm{V})$ and $\mathrm{V}(\mathrm{IV})$ is added last of all to a $50 \mathrm{mM} \mathrm{Mo}(\mathrm{VI})-0.3 \mathrm{M} \mathrm{HCl}-70 \%(\mathrm{v} / \mathrm{v}) \mathrm{CH}_{3} \mathrm{CN}$ system, only $\mathrm{V}(\mathrm{V})$ reacts with $\mathrm{Mo}(\mathrm{VI})$ to form a 12-molybdovanadate $(\mathrm{V})$ complex which undergoes a two-step reduction at the glassy carbon (GC) electrode; the reduction current is directly proportional to the $\mathrm{V}(\mathrm{V})$ concentration in the mixture. On the other hand, when $\mathrm{HCl}$ is added last after heating the $\mathrm{Mo}(\mathrm{VI})-\mathrm{CH}_{3} \mathrm{CN}$ system containing a mixture of $\mathrm{V}(\mathrm{V})$ and $\mathrm{V}(\mathrm{IV})$ at $60^{\circ} \mathrm{C}$ for $10 \mathrm{~min}, \mathrm{~V}(\mathrm{IV})$ is completely oxidized to $\mathrm{V}(\mathrm{V})$, and the total concentration of vanadium is determined. The $\mathrm{V}(\mathrm{IV})$ concentration is determined by subtracting the $\mathrm{V}(\mathrm{V})$ concentration before oxidation from the total concentration of vanadium. Interferences from foreign ions are also discussed.
\end{abstract}

Keywords 12-Molybdovanadate(V), voltammetric determination, vanadium(V), vanadium(IV)

The formation of the so-called Keggin-type heteropoly-complex has been the basis for a widely utilized determination of oxoanions. ${ }^{1}$ However, most studies have been limited to the determination of several oxoanions such as phosphate, arsenate, silicate and germanate. Increasing attention has been paid to the development of new methods based on the formation of heteropoly-complexes incorporating various types of oxoanions. Recently, we found that a water-soluble $\left[\mathrm{CrMo}_{6} \mathrm{O}_{24} \mathrm{H}_{6}\right]^{3-}$ anion was readily formed by the reaction of $\mathrm{Mo}(\mathrm{VI})$ with $\mathrm{Cr}(\mathrm{III})$ in an aqueous solution of pH 2 - 3; this reaction was applied to the simultaneous determination of $\mathrm{Cr}(\mathrm{III})$ and $\mathrm{Cr}(\mathrm{VI})$ with capillary electrophoresis. ${ }^{2}$

The use of water-miscible organic solvents, such as $\mathrm{CH}_{3} \mathrm{CN}$ and $\mathrm{CH}_{3} \mathrm{COCH}_{3}$, as auxiliary solvents made it possible to develop several methods for the direct determination of oxoanions. In acidic media containing $\mathrm{CH}_{3} \mathrm{CN}, \mathrm{PHO}_{3}{ }^{2-}$ reacts directly with $\mathrm{Mo}(\mathrm{VI})$ to form a heteropolyanion which undergoes two-step reduction at the GC electrode; this reaction was utilized as the basis of a voltammetric determination of $\mathrm{PHO}_{3}{ }^{2-} .^{3}$ In the presence of $\mathrm{CH}_{3} \mathrm{COCH}_{3}$, the so-called heteropoly-blue species are obtained by the reaction of $\mathrm{SO}_{4}{ }^{2-}, \mathrm{PHO}_{3}{ }^{2-}$ and $\mathrm{P}_{2} \mathrm{O}_{7}{ }^{4-}$ with the $\mathrm{Mo}(\mathrm{VI})-\mathrm{Mo}(\mathrm{V})$ reagent. The colorforming reaction was used in the spectrophotometric determination of these three oxoanions. ${ }^{4,5}$ This behavior was also applied to the voltammetric determination of $\mathrm{SO}_{4}{ }^{2-} .6$

During the course of studies on the complex-forma-

\footnotetext{
$\doteqdot$ To whom correspondence should be addressed.
}

tion between $\mathrm{Mo}(\mathrm{VI})$ and various oxoanions in such aqueous organic media, we found that $\mathrm{V}(\mathrm{V})$ reacted with an acidic Mo(VI) solution to give a Keggin-type 12-molybdovanadate $(\mathrm{V})$ complex, $\left[\mathrm{VMo}_{12} \mathrm{O}_{40}\right]^{3-}$, which exhibited a two-step reduction wave at the GC electrode. ${ }^{7}$ Since the amount of the $\left[\mathrm{VMo}_{12} \mathrm{O}_{40}\right]^{3-}$ complex formed is proportional to the $\mathrm{V}(\mathrm{V})$ concentration, the voltammetric reduction current can be used to determine $\mathrm{V}(\mathrm{V})$. For the determination of $\mathrm{V}(\mathrm{IV})$, heating of the $\mathrm{Mo}(\mathrm{VI})-\mathrm{V}(\mathrm{IV})$ system containing $\mathrm{CH}_{3} \mathrm{CN}$ leads to the complete oxidation of $\mathrm{V}(\mathrm{IV})$ to $\mathrm{V}(\mathrm{V})$. This pretreatment makes it possible to determine V(IV).

Teshima et al. developed a flow injection method for the determination of $\mathrm{V}(\mathrm{V})$ and $\mathrm{V}(\mathrm{IV}){ }^{8}{ }^{8}$ Recently, capillary electrophoresis was also applied to the separation of $\mathrm{V}(\mathrm{V})$ and $\mathrm{V}(\mathrm{IV})$ after complexation with diethylenetriaminepentaacetic acid (DTPA). ${ }^{9}$ However, the voltammetric determinations of $\mathrm{V}(\mathrm{V})$ and $\mathrm{V}(\mathrm{IV})$ are quite few.

\section{Experimental}

The absorption spectra were obtained with a Hitachi Model U-3000 spectrophotometer. Voltammetric measurements were made with a microcomputer-controlled system. A Tokai GC rod (GC-30S) with a surface area of $0.071 \mathrm{~cm}^{2}$ was used as a working electrode. A platinum wire served as the counter electrode and an $\mathrm{Ag} / \mathrm{AgCl}$ electrode as the reference. Prior to each measurement, the GC electrode was polished manually with $0.25 \mu \mathrm{m}$ diamond slurry, and washed with distilled 
water in an ultrasonic bath. Unless otherwise noted, the voltage scan rate was set at $100 \mathrm{mV} / \mathrm{s}$. The voltammetric measurements were made at $25^{\circ} \mathrm{C}$.

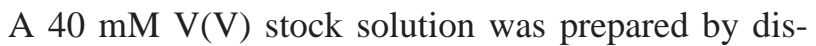
solving $\mathrm{NH}_{4} \mathrm{VO}_{3}$ in water. A stock solution of $\mathrm{V}(\mathrm{IV})$ was prepared by dissolving appropriate amount of $\mathrm{VOSO}_{4} \cdot n \mathrm{H}_{2} \mathrm{O}$ in $0.1 \mathrm{M} \mathrm{HCl}$; the vanadium content was determined with a Shimadzu Model ICPS-5000 inductively coupled argon plasma emission spectrometer. Sodium molybdate, $\mathrm{Na}_{2} \mathrm{MoO}_{4} \cdot 2 \mathrm{H}_{2} \mathrm{O}$ was used to prepare $\mathrm{Mo}(\mathrm{VI})$ stock solutions. All other reagents were of analytical grade and were used as received.

\section{Results and Discussion}

Reaction between $M o(V I)$ and $V(V)$ or $V(I V)$ in aqueous solution

With the addition of $\mathrm{V}(\mathrm{V})$ to a $50 \mathrm{mM} \mathrm{Mo}(\mathrm{VI})$ solution ( $\mathrm{pH}$ 3.0), as shown in Fig. 1(a), the solution turned to yellow, due to the formation of the monovanadium derivative of $\left[\mathrm{Mo}_{6} \mathrm{O}_{19}\right]^{2-}$; i.e., $\left[\mathrm{VMo}_{5} \mathrm{O}_{19}\right]^{3-} .{ }^{10}$ In contrast to the $\mathrm{Mo}(\mathrm{VI})-\mathrm{V}(\mathrm{IV})$ system, as discussed below, only the $\left[\mathrm{VMo}_{5} \mathrm{O}_{19}\right]^{3-}$ complex is isolated even in the presence of excess of $\mathrm{V}(\mathrm{V})$ with respect to $\mathrm{Mo}(\mathrm{VI})$. Wallace and Mellon applied this reaction to the spectrophotometric determination of $\mathrm{V}(\mathrm{V}) .^{11}$

On the other hand, a dark-purple solution was obtained upon the addition of a blue V(IV) solution to the $50 \mathrm{mM} \mathrm{Mo}(\mathrm{VI})$ solution around $\mathrm{pH}$ 6. As shown in Fig. 1(b), the solution exhibited an absorption maximum at $570 \mathrm{~nm}$, indicating the formation of some mixed molybdovanadate(IV) complexes. However, the compositional ratio of $\mathrm{Mo} / \mathrm{V}$ in the tetraalkylammonium salts of the dark-purple complexes depended on the V(IV) concentration added. Despite various attempts, the dark-purple molybdovanadate(IV) complex was not successfully prepared as a discrete polyanion. Besides, this color-forming reaction is not applied to the direct determination of V(IV) because the molar absorptivity of the dark-purple molybdovanadate(IV) complex is too low.

In order to compare their formation conditions, the absorbance values were plotted against the $\mathrm{pH}$ for the $50 \mathrm{mM} \mathrm{Mo}(\mathrm{VI})-5 \mathrm{mM} \mathrm{V}(\mathrm{V})$ or $\mathrm{V}(\mathrm{IV})$ systems, and are shown in Fig. 2. The yellow $\left[\mathrm{VMo}_{5} \mathrm{O}_{19}\right]^{3-}$ complex occurs predominantly around $\mathrm{pH} 2.5$ (Fig. 2(a)), while the dark-purple molybdovanadate(IV) complexes are formed in the $\mathrm{pH}$ range of $4-7$ (Fig. 2(b)).

Oxidation of $V(I V)$ to $V(V)$ through the formation of the dark-purple molybdovanadate(IV) complex

Preliminary experiments showed that the dark-purple molybdovanadate(IV) complexes were easily oxidized to $\mathrm{Mo}(\mathrm{VI})$ and $\mathrm{V}(\mathrm{V})$, compared to the blue $\mathrm{V}(\mathrm{IV})$ species. Figure $3(a, b)$ compares the absorbance values as a function of the reaction time for $2 \mathrm{mM} \mathrm{V(IV)-0.2}$ $\mathrm{M}$ carbonate buffer solutions ( $\mathrm{pH}$ 6) in the presence and absence of $50 \mathrm{mM} \mathrm{Mo}(\mathrm{VI})$. The absorbance values at $570 \mathrm{~nm}$ were measured after heating a solution for some period at $60^{\circ} \mathrm{C}$; the period is denoted as the reaction time. As shown in Fig. 3(a), the blue V(IV) species are rather stable against air-oxidation, even in neutral solutions. On the other hand, the dark-purple molybdovanadate(IV) species, which is readily formed by the reaction of $\mathrm{Mo}(\mathrm{VI})$ and $\mathrm{V}(\mathrm{IV})$, are easily oxidized to $\mathrm{Mo}(\mathrm{VI})$ and $\mathrm{V}(\mathrm{V})$. Accordingly, the absorbance values at $570 \mathrm{~nm}$ decreased abruptly (Fig. 3(b)). Furthermore, the presence of $\mathrm{CH}_{3} \mathrm{CN}$ at concentrations $>30 \%(\mathrm{v} / \mathrm{v})$ accelerated the oxidation reaction of the dark-purple species (Fig. 3(c)), whereas the stability of the free V(IV) species was practically unchanged by the presence of $\mathrm{CH}_{3} \mathrm{CN}$. The oxidation reaction became faster by the increase of the $\mathrm{CH}_{3} \mathrm{CN}$ concentration. It was also found that as a result of the reaction between $\mathrm{Mo}(\mathrm{VI})$ and $\mathrm{V}(\mathrm{V})$, the yellow $\left[\mathrm{VMo}_{5} \mathrm{O}_{19}\right]^{3-}$

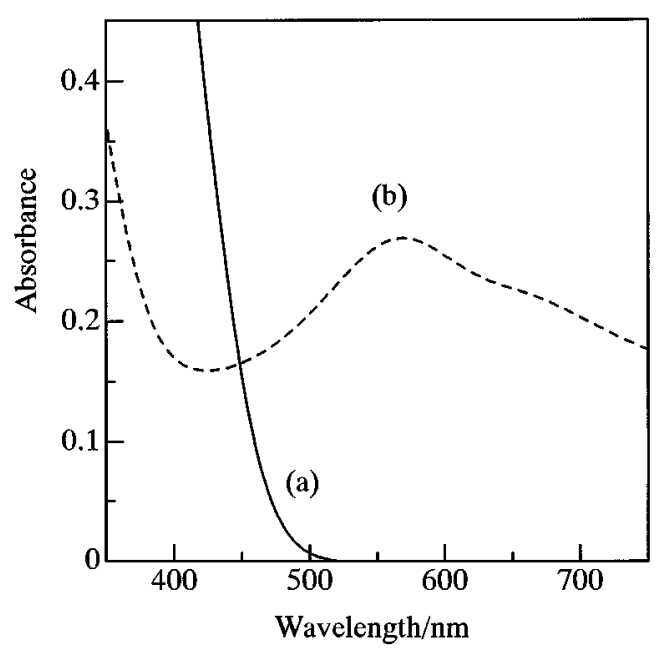

Fig. 1 UV-visible spectra for a $50 \mathrm{mM} \mathrm{Mo(VI)} \mathrm{solution} \mathrm{con-}$ taining (a) $5 \mathrm{mM} \mathrm{V(V)} \mathrm{(pH} \mathrm{3);} \mathrm{(b)} 5 \mathrm{mM} \mathrm{V(IV)} \mathrm{(pH} \mathrm{6).} \mathrm{Path}$ length, $1 \mathrm{~cm}$.

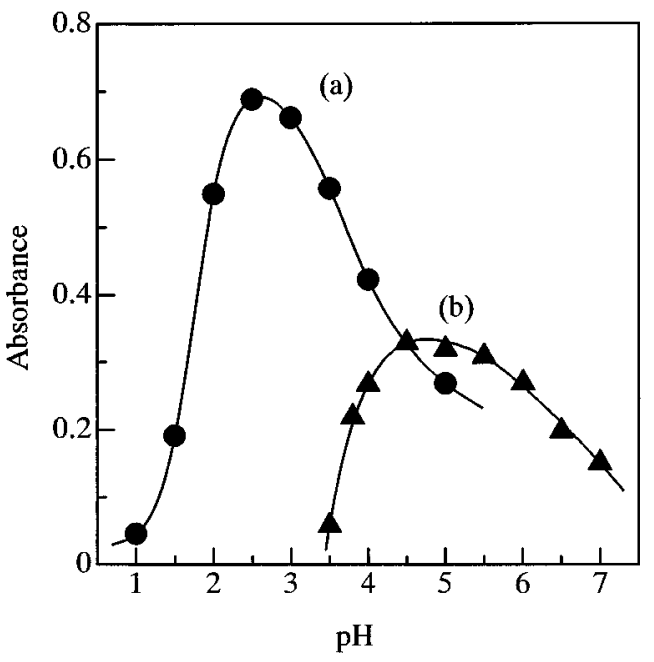

Fig. 2 Relationship between the absorbance values and $\mathrm{pH}$ for a $50 \mathrm{mM} \mathrm{Mo(VI)} \mathrm{solution} \mathrm{containing} \mathrm{(a)} 5 \mathrm{mM} \mathrm{V(V)}$ (at 400 nm); (b) $5 \mathrm{mM} \mathrm{V(IV)} \mathrm{(at} 570 \mathrm{~nm}$ ). Path length, $1 \mathrm{~cm}$. 


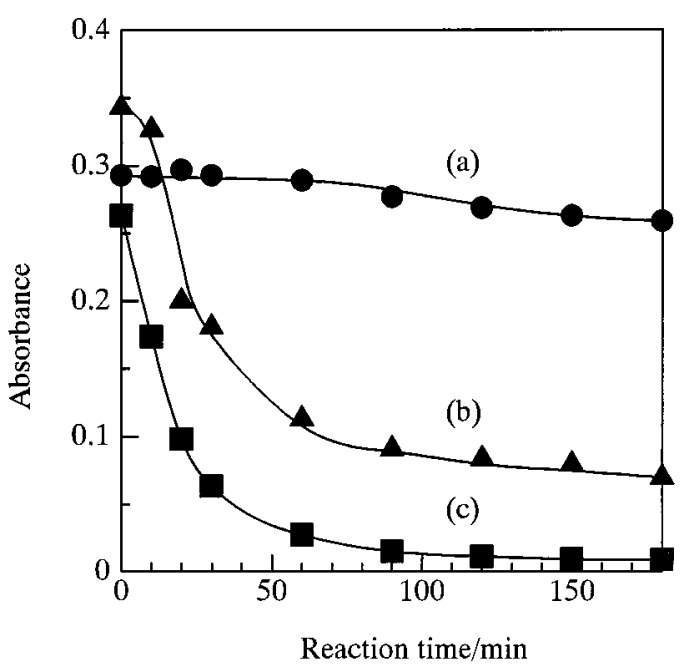

Fig. 3 Absorbance change (at $570 \mathrm{~nm}$ ) with time for (a) a 2 $\mathrm{mM} \mathrm{V(IV)} \mathrm{solution} \mathrm{(} \mathrm{pH}$ 6); (b) a $50 \mathrm{mM} \mathrm{Mo(VI)-2} \mathrm{mM}$ $\mathrm{V}(\mathrm{IV})$ solution (pH 6); (c) a $50 \mathrm{mM} \mathrm{Mo(VI)-2} \mathrm{mM} \mathrm{V(IV)-}$ $30 \%$ (v/v) $\mathrm{CH}_{3} \mathrm{CN}$ solution. Absorbance values were measured after heating the solution at $60^{\circ} \mathrm{C}$. Path length, $1 \mathrm{~cm}$.

complex was subsequently formed in both aqueous and aqueous- $\mathrm{CH}_{3} \mathrm{CN}$ media.

Optimization for the formation conditions of the Keggin-type 12-molybdovanadate(V) complex in aqueous organic solution

As described above, the presence of water-miscible organic solvents leads to the formation of the yellow $\left[\mathrm{VMo}_{5} \mathrm{O}_{19}\right]^{3-}$ complex at weaker acidities. On the other hand, a Keggin-type $\left[\mathrm{VMo}_{12} \mathrm{O}_{40}\right]^{3-}$ complex is formed at stronger acidities in the presence of organic solvents, probably due to a lower relative permittivity. Figure 4 shows cyclic voltammograms for a $50 \mathrm{mM} \mathrm{Mo(VI)-0.3}$ $\mathrm{M} \mathrm{HCl}-50 \%(\mathrm{v} / \mathrm{v}) \mathrm{CH}_{3} \mathrm{CN}$ system. In the absence of $\mathrm{V}(\mathrm{V})$, no reduction waves were observed until the current rise due to the reduction of $\left[\mathrm{Mo}_{6} \mathrm{O}_{19}\right]^{2-}$ (Fig. 4(a)). ${ }^{12}$ With the addition of $0.1 \mathrm{mM} \mathrm{V}(\mathrm{V})$, as shown in Fig. 4(b), a well-defined two-step reduction wave with an equal height appeared with peak-potentials at 0.34 and $0.24 \mathrm{~V}$. The reduction current was unchanged, after attaining a constant value within a few minutes at ambient temperature. As already described ${ }^{7}$, each of the two-step wave corresponds to a two-electron reduction of the molybdenum atoms in the peripheral position of the $\left[\mathrm{VMo}_{12} \mathrm{O}_{40}\right]^{3-}$ complex; the first reduction current is denoted as $i_{1}$. This behavior is the basis for the determination of $\mathrm{V}(\mathrm{V})$ because the reduction current increased linearly with an increase of the $V(V)$ concentration up to $1 \mathrm{mM}$. With further addition of $\mathrm{V}(\mathrm{V})$, a new reduction current, denoted as $i_{2}$, appeared at more positive potentials than the first wave for the $\left[\mathrm{VMo}_{12} \mathrm{O}_{40}\right]^{3-}$ complex (Fig. 4(c)), indicating the formation of vanadium-substituted mixed complexes, $\left[\mathrm{H}_{x-1} \mathrm{~V}\left(\mathrm{~V}_{x} \mathrm{Mo}_{12-x}\right) \mathrm{O}_{40}\right]^{4-}(x=1-3) .{ }^{10}$ The current, $i_{2}$ is due to a reduction of the peripheral vanadium atoms in

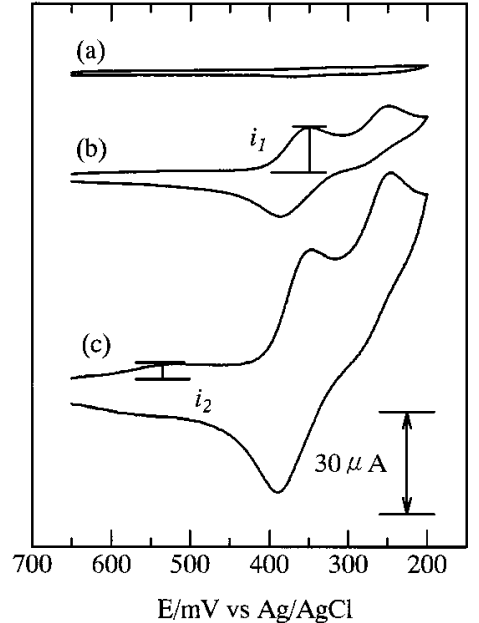

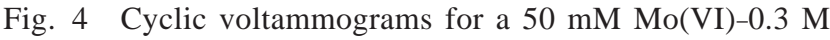
$\mathrm{HCl}-50 \%(\mathrm{v} / \mathrm{v}) \mathrm{CH}_{3} \mathrm{CN}$ system with (a) none; (b) $0.1 \mathrm{mM}$ $\mathrm{V}(\mathrm{V})$; (c) $2 \mathrm{mM} \mathrm{V}(\mathrm{V})$.

the mixed complexes. The linear plot of $i_{1}$ against the $\mathrm{V}(\mathrm{V})$ concentration curved downwards at $\mathrm{V}(\mathrm{V})$ concentrations $>1 \mathrm{mM}$, owing to the formation of the mixed complexes. The increase in the $\mathrm{Mo}(\mathrm{VI})$ concentration caused the linear range to expand to higher $\mathrm{V}(\mathrm{V})$ concentrations.

In order to compare the formation conditions of the $\left[\mathrm{VMo}_{12} \mathrm{O}_{40}\right]^{3-}$ and $\left[\mathrm{H}_{x-1} \mathrm{~V}\left(\mathrm{~V}_{x} \mathrm{Mo}_{12-x}\right) \mathrm{O}_{40}\right]^{4-}$ complexes, a series of cyclic voltammograms were recorded for 50 $\mathrm{mM} \mathrm{Mo}(\mathrm{VI})-50 \%(\mathrm{v} / \mathrm{v}) \mathrm{CH}_{3} \mathrm{CN}$ systems containing various concentrations of $\mathrm{HCl}$, and $i_{1}$ and $i_{2}$ were measured at $\mathrm{V}(\mathrm{V})$ concentrations of 0.1 and $5 \mathrm{mM}$, respectively; the results are shown in Fig. 5. The formation of the $\left[\mathrm{VMo}_{12} \mathrm{O}_{40}\right]^{3-}$ complex became maximal around a $\mathrm{HCl}$ concentration of $0.3 \mathrm{M}$ (Fig. 5(a)), while the $\left[\mathrm{H}_{x-1^{-}}\right.$ $\left.\mathrm{V}\left(\mathrm{V}_{x} \mathrm{Mo}_{12-x}\right) \mathrm{O}_{40}\right]^{4-}$ complexes were favored at weaker acidities (Fig. 5(b)).

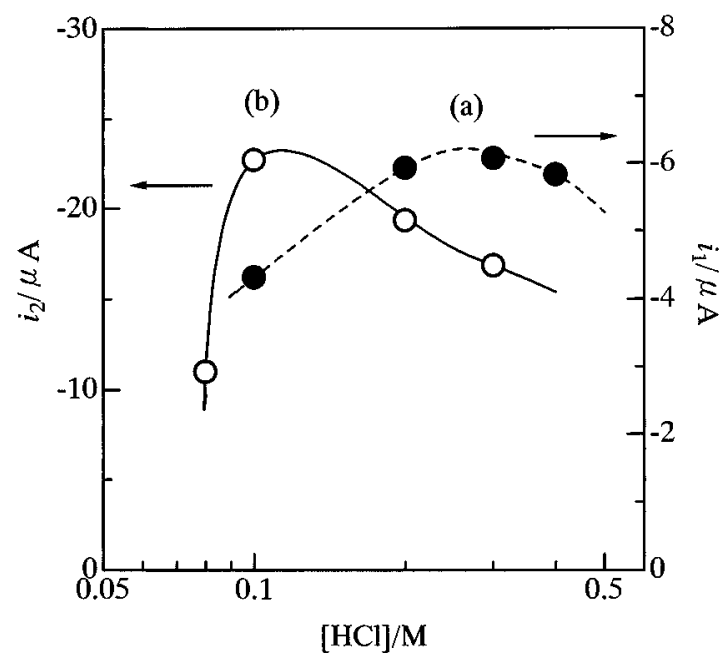

Fig. 5 Reduction currents as a function of the $\mathrm{HCl}$ concentration for $50 \mathrm{mM} \mathrm{Mo}(\mathrm{VI})-50 \%(\mathrm{v} / \mathrm{v}) \mathrm{CH}_{3} \mathrm{CN}$ system with (a) 0.1 $\mathrm{mM} \mathrm{V}(\mathrm{V})\left(i_{1}\right)$; (b) $5 \mathrm{mM} \mathrm{V}(\mathrm{V})\left(i_{2}\right)$. 


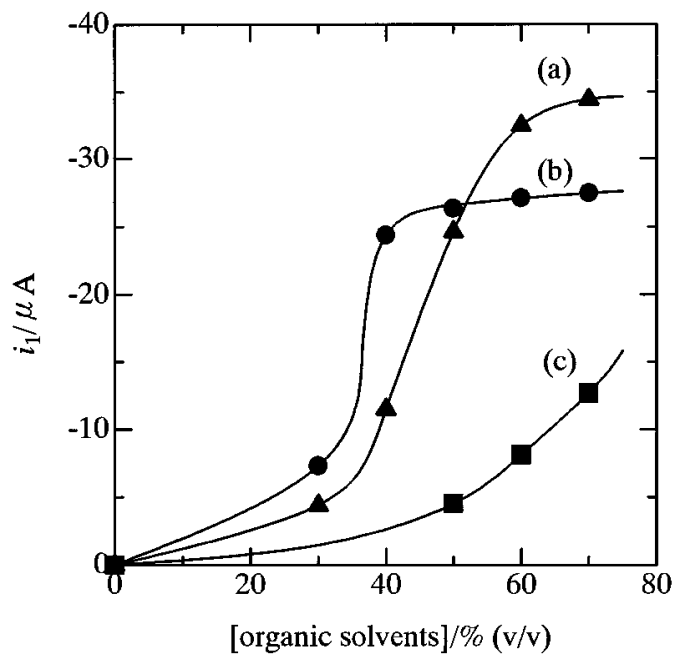

Fig. 6 Reduction currents $\left(i_{1}\right)$ for a $50 \mathrm{mM} \mathrm{Mo}(\mathrm{VI})-1 \mathrm{mM}$ $\mathrm{V}(\mathrm{V})-0.3 \mathrm{M} \mathrm{HCl}$ system containing various concentrations of (a) $\mathrm{CH}_{3} \mathrm{CN}$; (b) $\mathrm{CH}_{3} \mathrm{COCH}_{3}$; (c) $\mathrm{C}_{2} \mathrm{H}_{5} \mathrm{OH}$.

The presence of water-miscible organic solvents is essential for the formation of the $\left[\mathrm{VMo}_{12} \mathrm{O}_{40}\right]^{3-} \mathrm{com}-$ plex. As far as the choice of organic solvents was concerned, $i_{1}$ was measured for a $50 \mathrm{mM} \mathrm{Mo}(\mathrm{VI})-1.0 \mathrm{mM}$ $\mathrm{V}(\mathrm{V})-0.3 \mathrm{M} \mathrm{HCl}$ system containing various concentrations of $\mathrm{CH}_{3} \mathrm{CN}, \mathrm{CH}_{3} \mathrm{COCH}_{3}$ or $\mathrm{C}_{2} \mathrm{H}_{5} \mathrm{OH}$. As shown in Fig. 6 , the $i_{1}$ value was increased monotonously as the concentration of the organic solvent was increased. Of the three organic solvents, $\mathrm{CH}_{3} \mathrm{CN}$ was preferable because the biggest $i_{1}$ value was obtained; a concentration of $70 \%(\mathrm{v} / \mathrm{v})$ was chosen as a compromise.

On the basis of these findings, the $50 \mathrm{mM} \mathrm{Mo(VI)}$ $-0.3 \mathrm{M} \mathrm{HCl}-70 \%(\mathrm{v} / \mathrm{v}) \mathrm{CH}_{3} \mathrm{CN}$ system was chosen as being optimum for the determination of $\mathrm{V}(\mathrm{V})$, because two separate phases resulted at $\mathrm{Mo}(\mathrm{VI})$ concentrations $>60 \mathrm{mM}$. Cyclic voltammograms were recorded for this system containing $\mathrm{V}(\mathrm{V})$, and the $i_{1}$ values are directly proportional to the $\mathrm{V}(\mathrm{V})$ concentrations in the range of $0.05-1 \mathrm{mM}$. An advantage of this method is that removal of dissolved oxygen is not required because the $\left[\mathrm{VMo}_{12} \mathrm{O}_{40}\right]^{3-}$ complex is reduced at potentials more positive than that of dissolved oxygen. Since $\mathrm{V}(\mathrm{IV})$ does not react with $\mathrm{Mo}(\mathrm{VI})$ in such strongly acidified aqueous- $\mathrm{CH}_{3} \mathrm{CN}$ media, this procedure gives only the $\mathrm{V}(\mathrm{V})$ concentration in the mixture of $\mathrm{V}(\mathrm{V})$ and V(IV).

On the other hand, the V(IV) concentration can be determined after oxidation to the $\left[\mathrm{VMo}_{5} \mathrm{O}_{19}\right]^{3-}$ complex by heating the aqueous $\mathrm{Mo}(\mathrm{VI})-\mathrm{V}(\mathrm{IV})$ system ( $\mathrm{pH}$ 6) containing $\mathrm{CH}_{3} \mathrm{CN}$. The $\left[\mathrm{VMo}_{5} \mathrm{O}_{19}\right]^{3-}$ complex transforms spontaneously into the Keggin-type $\left[\mathrm{VMo}_{12} \mathrm{O}_{40}\right]^{3-}$ complex in strongly acidified aqueousorganic media. ${ }^{10}$

Recommended procedure for the determination of $V(V)$

In a $20 \mathrm{ml}$ volumetric flask are placed $2 \mathrm{ml}$ of 500 $\mathrm{mM} \mathrm{Mo}(\mathrm{VI})$ and $0.6 \mathrm{ml}$ of $10 \mathrm{M} \mathrm{HCl}$, followed by the addition of $14 \mathrm{ml}$ of $\mathrm{CH}_{3} \mathrm{CN}$. After an appropriate amount of a $\mathrm{V}(\mathrm{V})$ sample solution is added to the mixture, the solution is diluted to the mark with distilled water. After standing the solution for a few minutes at ambient temperature, a cyclic voltammogram is recorded. After making sure that $i_{2}$ is not observed at this time, the $\mathrm{V}(\mathrm{V})$ concentration is determined by a comparison with the calibration curve. When the sample solution comprises $\mathrm{V}(\mathrm{V})$ and $\mathrm{V}(\mathrm{IV})$, this procedure gives only the $\mathrm{V}(\mathrm{V})$ concentration, because $\mathrm{V}(\mathrm{IV})$ does not react with $\mathrm{Mo}(\mathrm{VI})$ under these conditions. Actually, the presence of V(IV) in concentrations of up to $10 \mathrm{mM}$ did not interfere with the determination of $0.5 \mathrm{mM} \mathrm{V}(\mathrm{V})$.

Recommended procedure for the determination of $V(I V)$ and total $V(V(V)+V(I V))$

After the $\mathrm{pH}$ of a solution containing $2 \mathrm{ml}$ of $500 \mathrm{mM}$ $\mathrm{Mo}(\mathrm{VI})$ and an appropriate amount of a V(IV) sample solution is adjusted to $6,14 \mathrm{ml}$ of $\mathrm{CH}_{3} \mathrm{CN}$ is added. In order to oxidize $\mathrm{V}(\mathrm{IV})$, the solution is heated at $60^{\circ} \mathrm{C}$ for $10 \mathrm{~min}$. By this procedure, $\mathrm{V}(\mathrm{IV})$ is completely oxidized to $\mathrm{V}(\mathrm{V})$, which subsequently forms the $\left[\mathrm{VMo}_{5} \mathrm{O}_{19}\right]^{3-}$ complex. Upon the addition of $0.6 \mathrm{ml}$ of $10 \mathrm{M} \mathrm{HCl}$, the $\left[\mathrm{VMo}_{5} \mathrm{O}_{19}\right]^{3-}$ complex transforms spontaneously into the $\left[\mathrm{VMo}_{12} \mathrm{O}_{40}\right]^{3-}$ complex. The solution is transferred to a $20 \mathrm{ml}$ volumetric flask and is diluted to the mark with distilled water. When the sample solution contains both $\mathrm{V}(\mathrm{V})$ and $\mathrm{V}(\mathrm{IV})$, this procedure gives the total concentration of vanadium. Then, the $\mathrm{V}(\mathrm{IV})$ concentration is estimated by subtracting the $\mathrm{V}(\mathrm{V})$ concentration before oxidation from the total concentration of vanadium.

\section{Interferences from foreign ions}

The effects of foreign ions on the determination of vanadium were investigated for a $50 \mathrm{mM} \mathrm{Mo}(\mathrm{VI})-0.3$ $\mathrm{M} \mathrm{HCl}-70 \%(\mathrm{v} / \mathrm{v}) \mathrm{CH}_{3} \mathrm{CN}$ system containing $0.5 \mathrm{mM}$ $\mathrm{V}(\mathrm{V})+0.5 \mathrm{mM} \mathrm{V}(\mathrm{IV})$. Table 1 summarizes relative errors for the determination of $\mathrm{V}(\mathrm{V})$ and of the total concentration of vanadium, based on two procedures described above, respectively. The presence of $\mathrm{NaCl}$ at concentrations $<10^{-2} \mathrm{M}$ caused no significant interference. Nitrate ions did not interfere with the determination of the total concentrations of $\mathrm{V}(\mathrm{V})$ and $\mathrm{V}(\mathrm{IV})$, but caused positive errors for the determination of $\mathrm{V}(\mathrm{V})$, due to the oxidation of $\mathrm{V}(\mathrm{IV})$ to $\mathrm{V}(\mathrm{V})$. Oxoanions such as $\mathrm{PO}_{4}{ }^{3-}, \mathrm{AsO}_{4}{ }^{3-}, \mathrm{SiO}_{4}{ }^{4-}$ and $\mathrm{GeO}_{4}{ }^{4-}$ also produce the corresponding Keggin-type heteropoly-complexes under the recommended conditions. Since the Keggin complexes undergo a two-electron reduction at nearly the same potentials as the $\left[\mathrm{VMo}_{12} \mathrm{O}_{40}\right]^{3-}$ complex, the presence of such oxoanions caused serious positive errors. The presence of $\mathrm{SO}_{4}{ }^{2-}$ caused a slight positive error, owing to the formation of the Dawson-type $\left[\mathrm{S}_{2} \mathrm{Mo}_{18} \mathrm{O}_{62}\right]^{4-}$ complex. ${ }^{13,14}$ 
Table 1 Effect of foreign ions on the determination of (1) V(V) and (2) $\mathrm{V}(\mathrm{V})+\mathrm{V}(\mathrm{IV})$

\begin{tabular}{ccrr}
\hline \multirow{2}{*}{ Ion added as } & Concentration/M & \multicolumn{2}{c}{ Relative error, \% } \\
& & 1 & (2) \\
\hline \multirow{2}{*}{$\mathrm{NaCl}$} & $10^{-2}$ & +3 & +3 \\
& $10^{-3}$ & +2 & +1 \\
$\mathrm{NaNO}_{3}$ & $10^{-1}$ & +8 & 0 \\
& $10^{-2}$ & +6 & 0 \\
$\mathrm{Na}_{2} \mathrm{SiO}_{3}$ & $10^{-4}$ & +26 & +11 \\
& $10^{-5}$ & +11 & +3 \\
$\mathrm{Na}_{2} \mathrm{GeO}_{3}$ & $10^{-4}$ & +20 & +9 \\
& $10^{-5}$ & +11 & +4 \\
$\mathrm{NaH}_{2} \mathrm{PO}_{4}$ & $10^{-4}$ & +9 & +6 \\
& $10^{-5}$ & +8 & +2 \\
$\mathrm{Na}_{2} \mathrm{HAsO}_{4}$ & $10^{-4}$ & +26 & +13 \\
& $10^{-5}$ & +10 & +5 \\
$\mathrm{NaHSO}_{4}$ & $10^{-4}$ & +5 & +6 \\
& $10^{-5}$ & +3 & +4 \\
\hline
\end{tabular}

A $50 \mathrm{mM} \mathrm{Mo}(\mathrm{VI})-0.3 \mathrm{M} \mathrm{HCl}-70 \%(\mathrm{v} / \mathrm{v}) \mathrm{CH}_{3} \mathrm{CN}$ system containing $0.5 \mathrm{mM} \mathrm{V}(\mathrm{V})+5 \mathrm{mM} \mathrm{V}(\mathrm{IV})$.

Measured after heating at $60^{\circ} \mathrm{C}$ for $10 \mathrm{~min}$.

\section{References}

1. M. T. Pope, "Heteropoly and Isopoly Oxometalates", Springer-Verlag, Berlin, 1983.
2. S. Himeno, Y. Nakashima and K. Sano, Anal. Sci., 14, 369 (1998).

3. S. Himeno, T. Osakai and A. Saito, Talanta, 37, 1071 (1990).

4. T. Hori, M. Sugiyama and S. Himeno, Analyst[London], 113, 1639 (1988).

5. S. Himeno, T. Ueda, H. Niiya, I. Iwai and T. Hori, Anal. Sci., 13, 369 (1997).

6. T. Osakai, S. Himeno, A. Saito and T. Hori, J. Electroanal. Chem., 278, 217 (1990).

7. S. Himeno and A. Saito, Inorg. Chim. Acta, 171, 135 (1990).

8. N. Teshima, H. Itabashi and T. Kawashima, Chem. Lett., 1992, 2227; Anal. Sci., 10, 207 (1994).

9. A. Padarauskas and G. Schwedt, J. Chromatogr., A, 773, 351 (1997).

10. S. Himeno, T. Osakai and A. Saito, Bull. Chem. Soc. Jpn., 64, 21 (1991).

11. G. W. Wallace and M. G. Mellon, Anal. Chim. Acta, 23, 355 (1960).

12. T. Osakai, S. Himeno, A. Saito and T. Hori, J. Electroanal. Chem., 285, 209 (1990).

13. S. Himeno, T. Hori and A. Saito, Bull. Chem. Soc. Jpn., 62 , 2184 (1989).

14. T. Hori, O. Tamada and S. Himeno, J. Chem. Soc. Dalton Trans., 1989, 1491.

(Received March 16, 1998)

(Accepted May 6, 1998) 